\title{
Strategies to Increase the Selling Price of Coffee Through Product Diversification
}

\author{
$1^{\text {st }}$ Rina Indrayani \\ Department of Industrial Engineering \\ Sekolah Tinggi Teknologi Bandung \\ Bandung, Indonesia \\ rina@sttbandung.ac.id
}

\author{
$2^{\text {nd }}$ Ragil Pardiyono \\ Departement of Industrial engineering \\ Universitas Jenderal Achmad Yani \\ Bandung, Indonesia \\ ragilpardiyono@gmail.com
}

\begin{abstract}
Srikandi village is one of the coffee-producing villages in Pangalengan West Java. Most of the population are farmers. During this time the resulting coffee still has a selling price that is not optimal, so this research aims to create a marketing strategy to increase the selling price of coffee. With respondents as many as 32 people or 4 groups of farmers, and research instruments were questionnaires, test results obtained all valid instrument for $r$ count> $r$ table of and for reliable are0.755, results of the analysis are the strength of this business, a good coffee quality, spacious and labor market much. The disadvantage is the lack of capital, while the chances are that the global coffee market. To the threat is that in Pangalengan many farmers who produce the same yields. Based on research conducted by 4 obtained by the $X$ and $Y$ at 6.5 , so that the position of this business is in quadrant II Cartesian diagram. So the strategy that should be done is the coffee farmers should diversify the products, which means that farmers do not just sell coffee in the form of cherries alone, but must sell coffee in other forms, such as coffee are peeled, dried, in roasting coffee even milled.
\end{abstract}

Keywords--strategy, selling price, diversification

\section{INTRODUCTION}

Srikandi village is one of the coffee production centers in West Java. This coffee is famous for its sweet taste and fragrant aroma and certainly preferred by consumers in the area of West Java even outside of Java. Currently, the amount of coffee plants and coffee production also tends to decline because farmers do not cultivate it. This, of course, led to the selling price decline. Actually, the cause of the low-selling price of this is because farmers do not do additional processing of the crop. They merely plant, nurture, harvest and then sell them to the conditions they shaped coffee cherry. So there is no added value over the coffee fruit, and buyers receive a price they deem reasonable.

With the selling price received by the lower city, of course, this is a problem for farmers. And if only the coffee fruit is thought before it is sold, it will raise the selling price. But in fact many obstacles faced, so that farmers feel the need to evaluate their farm, whether they should be continued or switched to other crops that might add to his income.

Problems faced by coffee farmers in the village of Srikandi is so low that the selling price is not expected maximum turnover. Besides that problems that arise from these activities is a coffee farmer groups only make the process of harvesting then only sold to the city [1].

According to [1] Coffee is a commodity crop that has an important role in economic activities in Indonesia. Coffee is also one of Indonesia's export commodities are quite important as a producer of foreign exchange in addition to oil and gas. In addition to the export opportunities increasingly open, coffee in the domestic market is still quite large.

So that the necessary assessment of the strategy should be done by the farmers to the selling price and revenue increases. A strategy is the means used to achieve the ultimate goal (target). But the strategy is not just a plan. The strategy is a unified plan, strategy binding on all parts of the company into one. The strategy covering all important aspects of a business.

\section{METHOD}

A. SWOT analysis

Good business is if the business has a good strategy also in business. [2]. Besides the necessary business marketing process as an effort to deliver the product to the public. Marketing [3] is marketing is an organizational function and a series of processes to create, communicate and provide value to customers and to manage customer relationships in ways that benefit the organization and stakeholders.

In determine, marketing strategy analysis is needed. SWOT analysis (Strength, Weakness, Opportunity, Threat) is a way to observe the internal and external marketing environment [4].

SWOT Analysis is a strategic planning method used in an attempt to evaluate the effect of variables (internal or external), the strengths, weakness, opportunities, and threats of a project or a business venture. It involves specifying the objective business venture or project and identifying the factors - internal and external factors that are favorable and unfavorable to achieving that objective.

SWOT is the identity of the various factors systematically to formulate the service strategy. This analysis is based on the logic that maximizes the chances but simultaneously to minimize flaws and threats. SWOT analysis comparing between external factors and internal factors. 


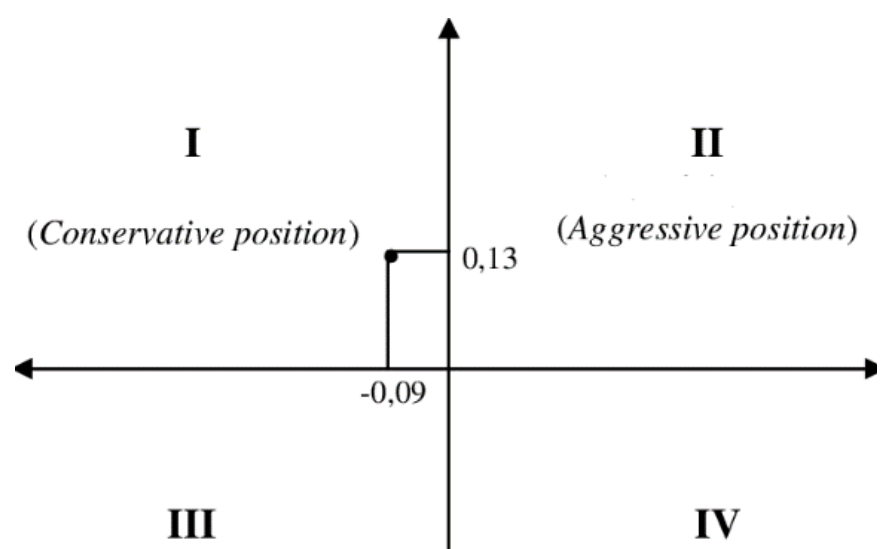

(Defensive position)

(Competitive position)

Figure 1. SWOT Analysis Diagram

\section{RESULT AND DISCUSSION}

Based on the analysis done by collecting data through questionnaires, it was found that the group of coffee farmers in the village of Srikandi have following things: Strength

a. Coffee Production Period Length

b. Easy workforce

c. Good Coffee Quality weaknesses:

a. Farmers lack capital

b. Not having a processing tool

c. Limited ability of farmers

d. Lower selling prices threats:

a. Every region in PANGALENGAN produce the same product

b. Competitors compete on price with other farmers opportunities:

a. Coffee is a worldwide harvest

b. Can export in the global market

c. Coffee quality requirements are easily met

d. Coffee demand is huge

e. Still great potential cultivation area

TABLE 1. TEST VALIDITY

\begin{tabular}{|c|c|c|c|c|}
\hline No. & Statement & $\begin{array}{c}\mathbf{R} \\
\text { arithmetic }\end{array}$ & $\begin{array}{c}\mathbf{R} \\
\text { table }\end{array}$ & Information \\
\hline 1 & $\mathrm{~A} 1$ & .650 & .3739 & valid \\
\hline 2 & $\mathrm{~A} 2$ & .750 & .3739 & valid \\
\hline 3 & $\mathrm{~A} 3$ & 0.465 & .3739 & valid \\
\hline 4 & $\mathrm{~A} 4$ & .650 & .3739 & valid \\
\hline 5 & $\mathrm{~A} 5$ & 0.668 & .3739 & valid \\
\hline 6 & $\mathrm{~A} 6$ & .750 & .3739 & valid \\
\hline 7 & $\mathrm{~A} 7$ & 0.465 & .3739 & valid \\
\hline 8 & $\mathrm{~A} 8$ & .750 & .3739 & valid \\
\hline 9 & $\mathrm{~A} 9$ & .589 & .3739 & valid \\
\hline 10 & $\mathrm{~A} 10$ & 0.668 & .3739 & valid \\
\hline 11 & $\mathrm{~A} 11$ & .417 & .3739 & valid \\
\hline 12 & $\mathrm{~A} 12$ & 0.578 & .3739 & valid \\
\hline 13 & $\mathrm{~A} 13$ & .650 & .3739 & valid \\
\hline 14 & $\mathrm{~A} 14$ & .750 & .3739 & valid \\
\hline
\end{tabular}

\begin{tabular}{|l|l|l|l|l|}
\hline 15 & A15 & .589 & .3739 & valid \\
\hline 16 & A16 & .750 & .3739 & valid \\
\hline 17 & A17 & .650 & .3739 & valid \\
\hline
\end{tabular}

From the above table that the value of $r$ count $>r$ table of means, the instruments used are valid. This means that the measuring instrument used was appropriate. As for the reliability contained in the table below, indicate reliability or reliable.

TABLE 2 TEST RELIABILITY

\begin{tabular}{|c|c|c|c|}
\hline variables & Alpha & Ket & \\
\hline External factors & 0755 & reliable & \\
\hline
\end{tabular}

\section{TABLE 3. WEIGHTING}

\begin{tabular}{|c|c|c|}
\hline Reliable & Alpha & Ket \\
\hline $\begin{array}{c}\text { External } \\
\text { factors }\end{array}$ & 0755 & reliable \\
\hline
\end{tabular}

\begin{tabular}{|c|c|c|c|c|}
\hline No. & Factor & Specialists & Weight & Score \\
\hline & Factors Strength (Strength) & & & \\
\hline 1 & $\begin{array}{l}\text { Coffee positive image of } \\
\text { Pangalengan }\end{array}$ & 3 & 5 & 15 \\
\hline 2 & $\begin{array}{lr}\begin{array}{l}\text { Means of } \\
\text { infrastructures } \\
\text { obtained }\end{array} & \text { production } \\
& \text { easily }\end{array}$ & 2 & 5 & 10 \\
\hline 3 & Long-term production period & 3 & 5 & 15 \\
\hline 4 & $\begin{array}{l}\text { Long-term coffee cultivation } \\
\text { techniques }\end{array}$ & 3 & 5 & 15 \\
\hline 5 & $\begin{array}{l}\text { Labor from the surrounding } \\
\text { environment }\end{array}$ & 3 & 5 & 14 \\
\hline \multicolumn{3}{|c|}{ amount } & & 69 \\
\hline No. & $\begin{array}{ll}\text { Weakness } & \text { factor } \\
\text { (Weakness) } & \\
\end{array}$ & & & \\
\hline 1 & $\begin{array}{l}\text { Less capital for the } \\
\text { development of farming }\end{array}$ & 4 & 4 & 16 \\
\hline 2 & $\begin{array}{l}\text { The results have not been up } \\
\text { coffee processing }\end{array}$ & 3 & 4 & 12 \\
\hline 3 & $\begin{array}{l}\text { Farming less empowered } \\
\text { groups }\end{array}$ & 4 & 4 & 16 \\
\hline 4 & Is the need for an engine & 4 & 4 & 16 \\
\hline \multicolumn{3}{|c|}{ amount } & & 60 \\
\hline No. & $\begin{array}{l}\text { Factors Opportunities } \\
\text { (Opportunities) }\end{array}$ & & & \\
\hline 1 & $\begin{array}{l}\text { Coffee quality requirements } \\
\text { are easily met }\end{array}$ & 3 & 4 & 12 \\
\hline 2 & Coffee demand is huge & 3 & 4 & 12 \\
\hline 3 & $\begin{array}{l}\text { Good relationships } \\
\text { suppliers (city) Coffee }\end{array}$ & 2 & 4 & 8 \\
\hline 4 & $\begin{array}{ll}\text { Still great potential } \\
\text { cultivation area }\end{array}$ & 3 & 4 & 12 \\
\hline \multicolumn{3}{|c|}{ amount } & & 44 \\
\hline No. & Factor Threat (Threat) & & & \\
\hline 1 & $\begin{array}{l}\text { Many competitors from other } \\
\text { regions }\end{array}$ & 3 & 4 & 12 \\
\hline 2 & $\begin{array}{l}\text { The increase in the price of } \\
\text { coffee }\end{array}$ & 4 & 4 & 16 \\
\hline 3 & Pests and diseases & 3 & 4 & 1 \\
\hline 4 & Effect of changes in engine & 4 & 4 & 16 \\
\hline \multicolumn{3}{|c|}{ amount } & & 56 \\
\hline
\end{tabular}

Based on the analysis above obtained $\mathrm{X}$ by 4.5 and $\mathrm{Y}$ for -6 , so that the position uasaha coffee farmers in quadrant II, the strategy that should be used is the strategy 
of ST / Strength - Threats or product diversification strategy.

ST strategy is a strategy that uses the power possessed to avoid any threat of external environment will affect the farmer's business. Strategies that can be used, among others sell coffee with diversification strategy, which means that farmers do not just sell coffee in any form or harvest cherries immediately sold, but farmers have to do the processing, for example through selling coffee that are peeled, dried, in roasting.

\section{CONCLUSION}

Based on the above analysis shows that the strengths and opportunities owned by then, the coffee farmers should do to diversify the product produced. Additional production through processing of coffee, the coffee farmer can sell his coffee in a variety of types. Products sold are coffee cherries, coffee peeled, dried coffee and coffee that has been roasting or roasted.

\section{REFERENCES}

[1] Indrayani, R., Mulyasari, D. and Hermawanto, A.R. Peningkatan Harga Jual Kopi Melalui Pelatihan Penggunaan Mesin Pengupas dan Pengering. SINDIMAS, 1(1), pp.217-221. 2019

[2] Indrayani. R dan Kasnadi, Pengantar Bisnis. Bandung, Landasan Ilmu, 2019.

[3] Indrayani, R. Analisis Pengaruh Bauran Pemasaran Terhadap Keputusan Pemilihan Perguruan Tinggi Serta Implikasinya Pada Kepuasan Mahasiswa. Jurnal Logistik Bisnis, 2(1), pp.85-95. 2011.

[4] Indrayani, R dan Pardiyono, R, Merancang Strategi pemasaran untuk meningkatkan omzet penjualan. Jurnal Sistemik Vol.5 No.1, 2011. 